\title{
Effective biomarkers for successful management of sepsis
}

\author{
Yasser El-Nahhal* and Ahmed Al_Shareef \\ Department of Toxicology, Faculty of science, The Islamic University Gaza, Palestine
}

\begin{abstract}
Background: The main objective of this study was to demonstrate the effectiveness of daily measurements of liver enzymes along with c-reactive protein (CRP), and complete blood count $(\mathrm{CBC})$ for the successful management of septic cases in neonates.

Method: A sample of septic neonates (48 individuals), along with 40 non-septic neonates, was randomly selected for the daily measurement of liver function tests (aspartate aminotransferase (AST), alanine aminotransferase (ALT), and alkaline phosphatase (ALP)), blood culture, CRP, and CBC during the routine medical treatments of sepsis cases in neonates. The abovementioned parameters were measured according to international laboratory standards. Data were statistically analyzed to determine whether there were correlations among parameters.

Results: The data showed elevated levels of white blood cells (WBCs), ALT, AST, ALP, and CRP and a reduced level of platelets on the first day of medical treatment (on admission). Daily measurement of the parameters provides a trend with the direction of medical treatment. Strong correlations were found between CRP and blood parameters. Successful medical treatment indicated a continuous reduction of WBCs, ALT, ALP, AST and CRP and increased level of platelets to reach the values of the reference range and/or the control group at the end point.
\end{abstract}

Conclusion: Daily measurements of ALT, AST, ALP and CRP along with blood counts are driving toward the successful diagnosis and management of septic cases in neonates. The implementation of these diagnostic parameters around the globe may reduce the morbidity and mortality in neonates.

\begin{abstract}
Abbreviations: AST: Aspartate aminotransferase; ALP: Alanine aminotransferase; ALP: Alkaline phosphatase; CRP: C-reactive protein; CBC: Complete blood count; WBC: White blood count; HG: Hemoglobin; PLT: Platelet count

\section{Background}

Sepsis and septic shocks are leading causes of mortality in neonates worldwide. It is well known in the literature that sepsis remains a major cause of morbidity and mortality for neonates in many countries around the globe. The early diagnosis of sepsis among neonates is an important step toward its successful management. Previous diagnostic efforts included performing a clinical chorioamnionitis [1], assessing the role of infection and noninfectious inflammation in epidural analgesia-related fever on the mother-neonate relationship [2], assessing the prevalence and diversity of microbes in the amniotic fluid [3], evaluating the role of innate host defenses in susceptibility to early-onset neonatal sepsis [4], evaluating the role of bacteria on early-onset neonatal sepsis [5], assessing the frequency of low level bacteremia in infants from birth to two months of age [6], and analyzing the blood culture [7].
\end{abstract}

Furthermore, many authors emphasized the diagnostic values of biochemical aspects such as cerebrospinal fluid protein concentration in neonates [8-11], C-reactive protein in neonatal group B streptococcal infection [12,13], and serum 1,3 $\beta$-d-glucan assay in the early diagnosis of invasive fungal infections in a neonatal intensive care unit [14].

Moreover, several researchers highlighted the diagnostic value of neonatal blood count [15], indexes of leukocyte and neutrophil concentrations [16], plasma fibronectin level in sepsis screens in neonates [17], the value of thrombocytopenia [18], platelet count [19], and the value of serum procalcitonin [20]. A recent diagnosis [21] described the clinical future of severe sepsis signs and symptoms among neonates in Indonesia.
It is obvious that diagnostic efforts include clinical signs and symptoms, neonate blood counts, blood culture, and few biochemical investigations. The limitations of the abovementioned reports are that they focused on analyzing one blood parameter that was not enough to provide a complete picture of the septic case and its complications. Moreover, the abovementioned reports did not kinetically measure $\mathrm{CBC}$, blood biochemistry, or blood culture and did not find correlations among blood parameters. Additionally, these studies did not include the measurement of AST, ALT, and ALP (liver biomarkers) in the diagnosis of sepsis in neonates. Furthermore, the kinetics of WBCs, CRP, platelet levels, ALT, AST, and ALP levels in sepsis remain poorly investigated. This study was designed to demonstrate the effectiveness of daily measurements of liver enzymes along with CRP, and CBC for the successful management of septic cases in neonates and characterized the regression correlations among them during the medical treatment.

\section{Methods}

\section{Neonate population size}

Forty-eight neonates having at least three of the following signs and symptoms (hypothermia, hyperthermia, tachypnea, mild jaundice, cyanosis, hypoactive, or feeding, mild distress) Omran et al. [22] were randomly selected and included in the study. These cases were observed

${ }^{\star}$ Correspondence to: Prof Dr. Yasser El-Nahhal, Faculty of science, The Islamic University Gaza, Palestine, Tel: 00970599634708; Fax 009708264480; E-mail: y_el_nahhal@hotmail.com

Key words: $A L T, A S T, A L P, C R P, W B C$

Received: August 17, 2018; Accepted: September 05, 2018; Published: September 07, 2018 
for 6 months. Another forty neonates who did not have any of the signs mentioned above but were hepatized for physiological sickness and have no infection were also randomly chosen as the control group. The parents of the septic and the control groups were convinced to participate in the study, and they signed consent forms. The study was approved by the Ministry of Health and the Helsinki Committee for Human Rights.

\section{Blood collection}

Following the procedure previously described [23], venous blood samples $(2 \mathrm{~mL})$ were collected from each patient into K3-EDTA tubes and serum vacutainer tubes. Complete blood counts (CBCs) were performed within 2-4 hours of collection using an autoanalyzer (Cell-Dyn 1800 Sapphire, Abbott Diagnostics). CBC included white blood cell count (WBC), red blood cell count (RBC), hemoglobin $(\mathrm{Hb})$ concentration, and platelet count (PLT). The abovementioned parameters were measured every day to kinetically evaluate the movements of the parameters during the medical treatments.

\section{Blood cultures}

Blood samples were collected from the sepsis cases and transferred to a special sterile bottle. The microbes were identified in the bacteriology unit in the central laboratory at the Ministry of Health in Gaza using the polymerase chain reaction method.

\section{Measurement of blood parameters}

Determination of CRP: CRP levels were determined in the serum obtained from the septic cases only using a semiquantitative serological method according to Ministry of Health laboratory standards 2016. In this procedure, $50 \mu \mathrm{L}$ of serum was mixed with $50 \mu \mathrm{L}$ of CRP reagent (CRP Latex, Ref LXCRP005; LOT CL-1608-1/61; purchased from UK via an Israeli company) for 30 minutes. In case the CRP concentration was below $6 \mathrm{mg} / \mathrm{dl}$, nothing was observed in the mixture, whereas at concentrations above $6 \mathrm{mg} / \mathrm{dl}$, agglutination occurred. In this case, serial dilutions should be performed until we notice that no agglutination would occur. Then, CRP value would be calculated by multiplying the number 6 with dilution times during the measurements. In some cases, a concentration below $6 \mathrm{mg} / \mathrm{dl}$ was measured in a special laboratory. To date, CRP levels below $6 \mathrm{mg} / \mathrm{dl}$ have been considered to be negative according to the Ministry of Health [24].

Deamination of live enzymes: The serum was obtained from each blood sample by centrifugation at $3000 \mathrm{rpm}$ for $15 \mathrm{~min}$ at 10 ${ }^{\circ} \mathrm{C}$. The obtained serum was used to determine the activity of liver function enzymes [aspartate aminotransferase (AST) and alanine aminotransferase (ALT) and alkaline phosphatase (ALP)] according to a previously developed method [25] using commercially supplied kits, ref. number 1044199 10021, lot 60112654, purchased from DiaSys, Germany, through an Israeli company. AST and ALT activities were measured based on Reitman and Frrankel [26] using a commercially available kit for AST ref. numbers 126019910021, lot 60112076, and ALT kit ref. BXC0213D, lot 162254, from Bio-Merieux, purchased from an Israeli company. AST, ALT and ALP values were determined every day during the medical periods.

The percentage of enzyme activation was calculated according to equation 1. El-Nahhal et al. [27]

$$
\% \text { Relative Enzyme Activation }=\frac{(\mathrm{EAT})}{(\mathrm{EAR})}
$$

where EAT and EAR are the enzyme activity measured at a certain time in the sepsis cases and the enzyme activity of the control group (reference range), respectively.

\section{Antibiotic microbial response tests}

Dose response relationships were conducted in the hospital laboratory in accordance with the international method.

\section{Management and medical follow-up of the cases}

Three well-qualified medical teams from the main hospital in Gaza took care of the medical requirements and follow up of the cases according to the international methods. They observed the cases for $24 \mathrm{~h}$ in accordance with well-known international medical standards.

\section{Statistical analysis}

The septic cases were characterized into three groups according to the microbes that were detected. Individuals of each group were counted together. The means and standard deviations were calculated for each group during medical treatment in the intensive care unit. A t-test was used to detect a difference among means and to indicate whether a medical treatment for patient is still required or not. In the case of no significant differences were detected, this indicates that the patients were improved and can be released from the hospital.

$\mathrm{AST}_{0} / \mathrm{AST}_{\mathrm{t}}$ ratios were calculated and regressed vs medical treatment time, where $\mathrm{AST}_{0}$ and $\mathrm{AST}_{\mathrm{t}}$ are the initial and the final value after treatment, respectively. Furthermore, CRP values were regressed vs. AST, ALT, WBC, and PLT.

\section{Results}

\section{Blood culture and clinical signs}

Blood culture identified three microbial infections in the septic cases of the neonates. These microbes are E. Coli, Staphylococcus aureus and Klebsiella sp.; their infections in neonates are complicated and require careful attention during the medical follow-up period in the hospital.

The clinical signs of the septic groups are shown in Table 1. It is obvious that each case has thermal instability (hyperthermia or hypothermia), tachypnea, mild jaundice or cyanosis, hypoactivity, poor

Table 1. Blood culture and clinical symptoms

\begin{tabular}{|c|c|c|c|c|}
\hline Baby item & S. aureus. & E. coli & Klebsiella & Control group \\
\hline Thermia & Hypert & Hypo & Hypo & Normal \\
\hline Tachypnea & $\sqrt{ }$ & $\sqrt{ }$ & $\sqrt{ }$ & - \\
\hline Mild jaundice & $\sqrt{ }$ & $\sqrt{ }$ & - & $\sqrt{ }$ \\
\hline Cyanosis & - & - & $\sqrt{ }$ & - \\
\hline hypoactive & $\sqrt{ }$ & NGT & NGT & Normal \\
\hline Feeding mode & NGT & $\sqrt{ }$ & $\sqrt{ }$ & - \\
\hline poor feeding & $\sqrt{ }$ & Mild distress & Mild distress & - \\
\hline respiration & - & + & + & - \\
\hline blood culture & + & 15 & 14 & 40 \\
\hline patients & 19 & $9(60)$ & $7(50)$ & $23(57.5)$ \\
\hline Female & $10(52.6)$ & $6(40)$ & $7(50)$ & $17(42.5)$ \\
\hline Male & $9(47.4)$ & $34-36$ & $34-36$ & 38 \\
\hline $\begin{array}{c}\text { Gestational } \\
\text { age range } \\
\text { (weeks) }\end{array}$ & $34-36$ & $2.75-3.15$ & $2.70-3.16$ & $3.1-3.76$ \\
\hline Birth weight & $2.15-2.85$ & $36-39$ & $36-39$ & $36.8-37.4$ \\
\hline $\begin{array}{c}\text { Temperature } \\
\text { range }\end{array}$ & $36-39$ & & & \\
\hline
\end{tabular}

NGT: Nasogastric tube.

Values in brackets indicate $\%$ of the case under investigation. 
feeding and mild respiratory distress. These clinical signs are common in neonate septic cases.

\section{Blood parameters}

The kinetic measurements of blood parameters such as hemoglobin (HB), white blood cells (WBCs) and platelets (PLT) of forty septic cases in neonates are presented in Table 2. It can be seen that HB values are not significantly changed in the sepsis cases during the medical period in the intensive care unit. This indicates that HB is not directly involved in the complication of sepsis cases. However, it can be observed that $\mathrm{WBC}$ values are high on the $1^{\text {st }}$ day (on admission) and slowly decline during the medical treatment, becoming close to the value in the control group on the last day of medical treatments $\left(8^{\text {th }}\right.$ day). Moreover, the trend of WBCs is similar in the three microbial infections. Statistical analysis did not detect a significant difference in WBC values in the three microbial infections; however, significant differences were found in comparison with the same parameters in the control group.

In contrast, platelet values were the lowest on the $1^{\text {st }}$ day (on admission) and increased gradually to be the highest on the last day of medical treatment. The trend is similar in the other microbial infection groups. Statistical analysis did not detect significant differences among microbial infection groups, whereas significant differences were found with the control group. Moreover, it is obvious that the medical period of each microbial infection was 8 days; in some cases, the medical period reached 11 days, but those were excluded from the study.

Additionally, CRP values were at the highest value $(24 \mathrm{mg} / \mathrm{dl})$ on the first day of medical treatment; then, the value declined and was below $6 \mathrm{mg} / \mathrm{dl}$ on the $8^{\text {th }}$ day in all sepsis patients. However, CRP values remained at a high level on the $1^{\text {st }}$ and $2^{\text {nd }}$ days in the sepsis cases that were caused by E. Coli and Staphylococcus aureus during the medical treatment periods (Table 2). CRP was high during the maximum infection and declined below $6 \mathrm{mg} / \mathrm{dl}$, the normal range according to the standards of the Ministry of Health [24], due to medical treatments. Statistical analysis did not identify a significant difference.

However, CRP values are similar in all septic cases in neonates. The similarities of the values are a result of the measurement methods (qualitative descriptive method).

\section{Liver biomarkers}

Liver biomarkers of septic cases caused by E. Coli, Staphylococcus, Klebsiella and the control group are presented in Table 3.

Generally, ALT, AST and ALP values are higher on the first day of hospital admission ( $1^{\text {st }}$ day) than on the last day of medical treatment. This trend is similar in the three microbial infections in sepsis cases. However, ALT values on the $1^{\text {st }}$ day were higher in E. coli sepsis cases than in others. Statistical analysis detected significant differences. This suggests that E. coli caused liver damage more than the other types of sepsis. During medical treatment, ALT values of E. coli remained higher than those of other cases in the same day, suggesting complications of E. coli. Then, the levels tend to slow down to reach the normal range on the $8^{\text {th }}$ day of medical treatments.

The medical team gave the sepsis cases bacteria-sensitive antibiotics during the medical period. The decline in ALT, AST and ALP values during the medical period indicated the suppression and/or reduction of the microbial population. This is a leading step toward the successful management of sepsis. Comparison of liver enzymes among the three sepsis groups shows that E.coli raised liver biomarkers higher than Staphylococcus aureus and Klebsiella. This suggests that E. coli led to more complications in neonates. Accordingly, septic cases caused by E. coli required a longer treatment period than septic cases caused by Staphylococcus aureus or Klebsiella. To date, Staphylococcus aureus appeared to cause less effects on liver enzymes than did the others.

\section{Correlations among blood parameters}

Correlations between CRP/AST, ALP, and ALT are presented in Figure 1, and correlations between CRP and HB and WBC and PLT in sepsis cases with E. coli and Staphylococcus aureus are presented in Figure 2. It is clear that CRP/PLT correlation is strongly negative with an exponential mode, whereas the other correlations are strongly positive with an exponential mode. This suggests that the microbes have a similar mode of infection. We also concluded the correlations between relative elevations of enzyme vs time, as shown in Figure 3.

Table 2. Blood biomarker in neonate septic cases affected by E. coli and Staphylococcus aureus. Values (mean $\pm \mathrm{SD}$ ) that have the same letter/s in the same column (day) are not significantly different at $\mathrm{p}$-value $=0.05$

\begin{tabular}{|c|c|c|c|c|c|c|c|c|}
\hline \multirow{2}{*}{ Biomarker } & \multicolumn{8}{|c|}{ E. coli } \\
\hline & $1^{\text {st }}$ day & $2^{\text {nd }}$ day & $3^{\text {rd }}$ day & $4^{\text {th }}$ day & $5^{\text {th }}$ day & $6^{\text {th }}$ day & $7^{\text {th }}$ day & $8^{\text {th }}$ day \\
\hline HB & a18.00 \pm 1.00 & a17.20 \pm 0.69 & a17.87 \pm 1.15 & a17.47 \pm 0.35 & a17.40 \pm 1.01 & a16.83 \pm 1.04 & a15.33 \pm 1.61 & a15.47 \pm 1.10 \\
\hline WBCs & ab31.67 \pm 10.41 & $a b 29.83 \pm 9.44$ & $a b 30.03 \pm 8.60$ & ab26.83 \pm 7.49 & $a b 22.03 \pm 5.49$ & ab15.67 \pm 2.03 & ab13.90 \pm 3.61 & ab13.17 \pm 2.47 \\
\hline Platelets & ac72.00 \pm 24.33 & ac89.00 \pm 36.76 & ac95.00 \pm 26.46 & ac97.00 \pm 42.04 & ac121.33 \pm 44.61 & ac148.33 \pm 52.52 & ac216.67 \pm 70.24 & ac228.67 \pm 65.58 \\
\hline CRP & $\mathrm{d} 24.00 \pm 0.0$ & $\mathrm{~d} 24.00 \pm 0.0$ & $\mathrm{~d} 16.00 \pm 6.93$ & $\mathrm{~d} 14.67 \pm 8.33$ & $\mathrm{~d} 8.00 \pm 3.46$ & $\mathrm{~d} 6.33 \pm 5.01$ & $\mathrm{~d} 2.50 \pm 1.5$ & $\mathrm{~d} 2.00 \pm 1.0$ \\
\hline \multicolumn{9}{|c|}{ Staphylococcus aureus } \\
\hline & $1^{\text {st }}$ day & $2^{\text {nd }}$ day & $3^{\text {rd }}$ day & $4^{\text {th }}$ day & $5^{\text {th }}$ day & $6^{\text {th }}$ day & $7^{\text {th }}$ day & $8^{\text {th }}$ day \\
\hline HB & a $18.33 \pm 1.53$ & a17.30 \pm 0.85 & a17.83 \pm 1.65 & a17.17 \pm 0.81 & a16.67 \pm 0.29 & a17.17 \pm 0.58 & a17.00 \pm 1.41 & a16.55 \pm 2.90 \\
\hline WBCs & ab32.67 \pm 12.70 & $\mathrm{ab} 29.00 \pm 11.27$ & $\mathrm{ab} 24.33 \pm 9.50$ & $\mathrm{ab} 24.60 \pm 8.62$ & ab19.67 \pm 5.50 & $a b c 20.00 \pm 2.65$ & ac17.50 \pm 3.54 & ab14.75 \pm 3.89 \\
\hline PLT & ac73.33 \pm 20.82 & ac $90.00 \pm 5.00$ & ac107.33 \pm 21.94 & ac119.00 \pm 24.56 & ac173.33 \pm 46.19 & ac190.00 \pm 57.66 & $\operatorname{ad} 175.00 \pm 35.36$ & ac325.00 \pm 21.21 \\
\hline CRP & $\mathrm{d} 24.00 \pm 0.00$ & $\mathrm{~d} 20.00 \pm 6.93$ & $\mathrm{~d} 10.00 \pm 3.46$ & $\mathrm{~d} 8.00 \pm 3.46$ & $\mathrm{~d} 5.33 \pm 1.15$ & $\mathrm{~d} 4.33 \pm 1.76$ & $\mathrm{~d} 2.67 \pm 1.76$ & $\mathrm{~d} 1.67 \pm 0.76$ \\
\hline \multicolumn{9}{|c|}{ Klebsiella } \\
\hline HB & a16.85 \pm 0.49 & a17.00 \pm 1.13 & a16.65 \pm 0.21 & a16.60 \pm 0.85 & a16.45 \pm 0.35 & a16.35 \pm 0.21 & a16.35 \pm 0.21 & a16.50 \pm 0.99 \\
\hline WBCs & ab32.50 \pm 10.61 & $\mathrm{ab} 29.85 \pm 10.39$ & ab26.00 99.19 & $\mathrm{ab} 23.10 \pm 8.34$ & $\mathrm{ab} 22.70 \pm 8.20$ & Abc19.35 \pm 4.45 & ac16.05 14.45 & $\mathrm{ab} 13.50 \pm 2.47$ \\
\hline PLT & ac92 914.14 & ac95 \pm 7.07 & ac105 \pm 2.12 & ac135 14.95 & ac145 \pm 5.66 & ac $160 \pm 17.68$ & ac180 \pm 10.61 & ac190 \pm 3.54 \\
\hline CRP & $\mathrm{a} 24.00 \pm 00$ & $\mathrm{e} 12.00 \pm 00$ & $\mathrm{~d} 12.00 \pm 00$ & d6.00 \pm 00 & dd6.00 \pm 00 & $\mathrm{~d} 4.50 \pm 0.71$ & $\mathrm{~d} 3.25 \pm 0.35$ & $\mathrm{~d} 2.25 \pm 0.30$ \\
\hline \multicolumn{9}{|c|}{ Control group } \\
\hline $\mathrm{HB}$ & a16.5 2.51 & a17.5 \pm 2.67 & a14.5 \pm 3.45 & a15.3 \pm 3.21 & a15.95 \pm 1.97 & a16.5 \pm 1.87 & a17.5 \pm 2.86 & a14.5 \pm 0.58 \\
\hline WBC & ac11.2 \pm 3.21 & ac11.2 \pm 3.53 & ac12.1 $1 \pm 2.56$ & ac12.7 1.76 & ac11.8 \pm 1.85 & abd11.2 2.45 & ab11.2 2.35 & ab12.1 \pm 1.78 \\
\hline PLT & $\operatorname{ad} 210 \pm 15.72$ & $\operatorname{ad} 250 \pm 19.24$ & $\operatorname{ad} 310 \pm 22.51$ & $\operatorname{ad} 290 \pm 20.76$ & $\operatorname{ad} 265 \pm 18.35$ & $\operatorname{ad} 240 \pm 11.98$ & ac250 10.52 & ac300 25.5 \\
\hline
\end{tabular}


Table 3. Liver biomarker in neonate septic cases affected by E. Coli and Staphylococcus aureus. Values (mean \pm SD) in a column that have same letters are not significantly different at p-value $=0.05$

\begin{tabular}{|c|c|c|c|c|c|c|c|c|}
\hline \multirow{2}{*}{ Biomarker } & \multicolumn{8}{|c|}{ E. coli } \\
\hline & $1^{\text {st }}$ day & $2^{\text {nd }}$ day & $3^{\text {rd }}$ day & $4^{\text {th }}$ day & $5^{\text {th }}$ day & $6^{\text {th }}$ day & $7^{\text {th }}$ day & $8^{\text {th }}$ day \\
\hline ALT & a $73.33 \pm 14.74$ & a $57.33 \pm 6.43$ & a $58.33 \pm 3.51$ & ${ }^{a} 56.00 \pm 5.20$ & a58.33 \pm 15.37 & $\mathrm{a} 46.00 \pm 5.29$ & $\mathrm{a} 43.00 \pm 5.29$ & a38.00 \pm 1.00 \\
\hline AST & $\mathrm{ab} 69.00 \pm 9.64$ & $a b 57.00 \pm 1.73$ & $a b 55.67 \pm 8.02$ & $\mathrm{ab} 56.33 \pm 10.21$ & $a b 58.33 \pm 11.85$ & $a b 49.67 \pm 0.58$ & $a b 42.33 \pm 5.13$ & ab37.00 \pm 4.34 \\
\hline \multirow[t]{3}{*}{ ALP } & ac $250.00 \pm 50.00$ & ac236.67 \pm 55.08 & ac230.00 \pm 43.59 & ac223.33 \pm 40.41 & ac235.00 \pm 25.98 & ac190.00 \pm 36.06 & ac $186.67 \pm 15.28$ & ac166.67 \pm 15.28 \\
\hline & \multicolumn{8}{|c|}{ Staphylococcus aureus } \\
\hline & $1^{\text {st }}$ day & $2^{\text {nd }}$ day & $3^{\text {rd }}$ day & $4^{\text {th }}$ day & $5^{\text {th }}$ day & $6^{\text {th }}$ day & $7^{\text {th }}$ day & $8^{\text {th }}$ day \\
\hline ALT & ${ }^{\mathrm{b}} 60.0 \pm 4.5$ & a $55.00 \pm 7.0$ & ${ }^{\mathrm{b}} 50.00 \pm 5.0$ & $\mathrm{~b} 47.33 \pm 5.03$ & a47.00 \pm 6.08 & $\mathrm{a} 43.67 \pm 10.41$ & $\mathrm{a} 41.33 \pm 4.73$ & a39.00 \pm 4.24 \\
\hline AST & $\mathrm{ab} 60.0 \pm 10.00$ & ab55.67 \pm 12.10 & ab52.67 \pm 10.69 & ab53.67+13.65 & ab51.00 \pm 13.89 & $\mathrm{ab} 48.33 \pm 9.50$ & ab50.00 \pm 7.07 & ab41.50 \pm 4.95 \\
\hline \multirow[t]{2}{*}{ ALP } & ac233.33 \pm 28.87 & ac206.67 \pm 5.77 & ac207.33 \pm 6.43 & ac203.33 \pm 15.28 & ac205.00 \pm 5.00 & ac201.67 \pm 7.64 & 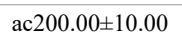 & ac181.67 \pm 2.89 \\
\hline & \multicolumn{8}{|c|}{ Klebsiella } \\
\hline ALT & $\mathrm{c} 56.00 \pm 5.66$ & a53.50土12.02 & a53.50 \pm 16.26 & $\mathrm{c} 48.00 \pm 14.14$ & $\mathrm{a} 43.50 \pm 12.02$ & $\mathrm{a} 40.00 \pm 11.31$ & a37.50 \pm 10.61 & a35.50土9.19 \\
\hline AST & $a b 56.50 \pm 2.12$ & $a b 54.50 \pm 7.78$ & ab53.50土12.02 & $\mathrm{ab} 47.50 \pm 10.61$ & $a b 44.50 \pm 9.19$ & $a b 42.00 \pm 9.90$ & $\mathrm{ab} 39.00 \pm 7.78$ & ab39.50 \pm 8.49 \\
\hline \multirow[t]{2}{*}{ ALP } & aa200.00 \pm 0.00 & ac200.00土11.12 & ac200.00土14.14 & ac200.00 \pm 7.5 & ac200.00土9.14 & ac2 $10.00 \pm 10.61$ & $\mathrm{ac} 217.50 \pm 21.21$ & 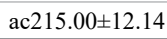 \\
\hline & \multicolumn{8}{|c|}{ Control group } \\
\hline ALT & c $39.0 \pm 12.21$ & ${ }^{b} 32 \pm 3.42$ & c $42 \pm 3,77$ & $\mathrm{~b} 41 \pm 5.93$ & $\mathrm{a} 42 \pm 5.48$ & $\mathrm{a} 45 \pm 5.92$ & $\mathrm{a} 40 \pm 3.95$ & $\mathrm{a} 43 \pm 5.43$ \\
\hline AST & ac41 49.83 & ac39 5.61 & ac $45 \pm 2.93$ & ac $38 \pm 8.75$ & $\mathrm{ab} 46 \pm 7.57$ & $\mathrm{ab} 46 \pm 8.33$ & $\mathrm{ab} 40 \pm 4.76$ & $a b 43 \pm 8.26$ \\
\hline ALP & $\operatorname{ad} 185 \pm 5.33$ & $\operatorname{ad} 175 \pm 5.36$ & $\operatorname{ad} 175 \pm 4.32$ & $\operatorname{ad} 170 \pm 9.85$ & $\operatorname{ad} 182 \pm 8.96$ & ac178 \pm 12.74 & ac204 \pm 15.84 & ac183 \pm 13.92 \\
\hline
\end{tabular}
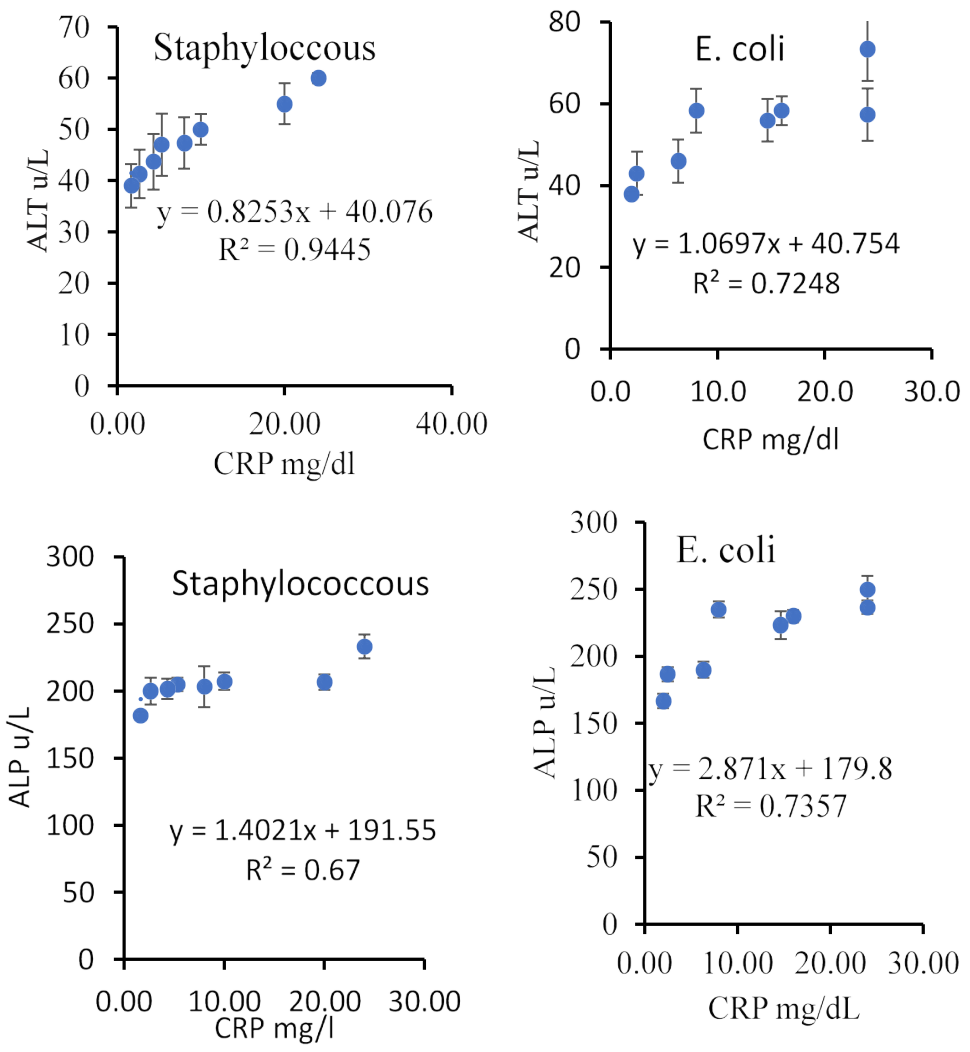

Figure 1. Correlations between CRP and ALT, AST and ALP in septic cases with E. coli and Staphylococcus aureus. Error bars represent the standard deviation

\section{Discussion}

The main objective of this study was to demonstrate the effectiveness of daily measurements of liver enzymes along with CRP, and CBC for the successful management of septic cases in neonates.

Our data show the effective use of several parameters such as blood culture, blood counts (HG, WBC, and PLT), CRP, ALT, AST and ALP and the statistical correlations among these parameters. The data in Table 1 clearly show the clinical signs of neonatal septic cases. These signs are in agreement with the septic signs characterized by Omran et al. [22], who revealed that the clinical findings of sepsis included the presence of three or more of the following: (1) temperature instability (hypothermia or hyperthermia); (2) respiratory alterations (grunting, intercostal retractions, apnea, tachypnea, or cyanosis); (3) cardiovascular alterations (bradycardia, tachycardia, poor perfusion, or hypotension); (4) neurologic alterations (hypotonia, lethargy, or seizures); and (5) gastrointestinal alterations (feeding intolerance).

The blood culture indicated the presence of E. coli, Staphylococcus aureus, and Klebsiella sp. in the blood of the neonates. This indicates the possibility of multi-organ infection. As a result of this microbial 

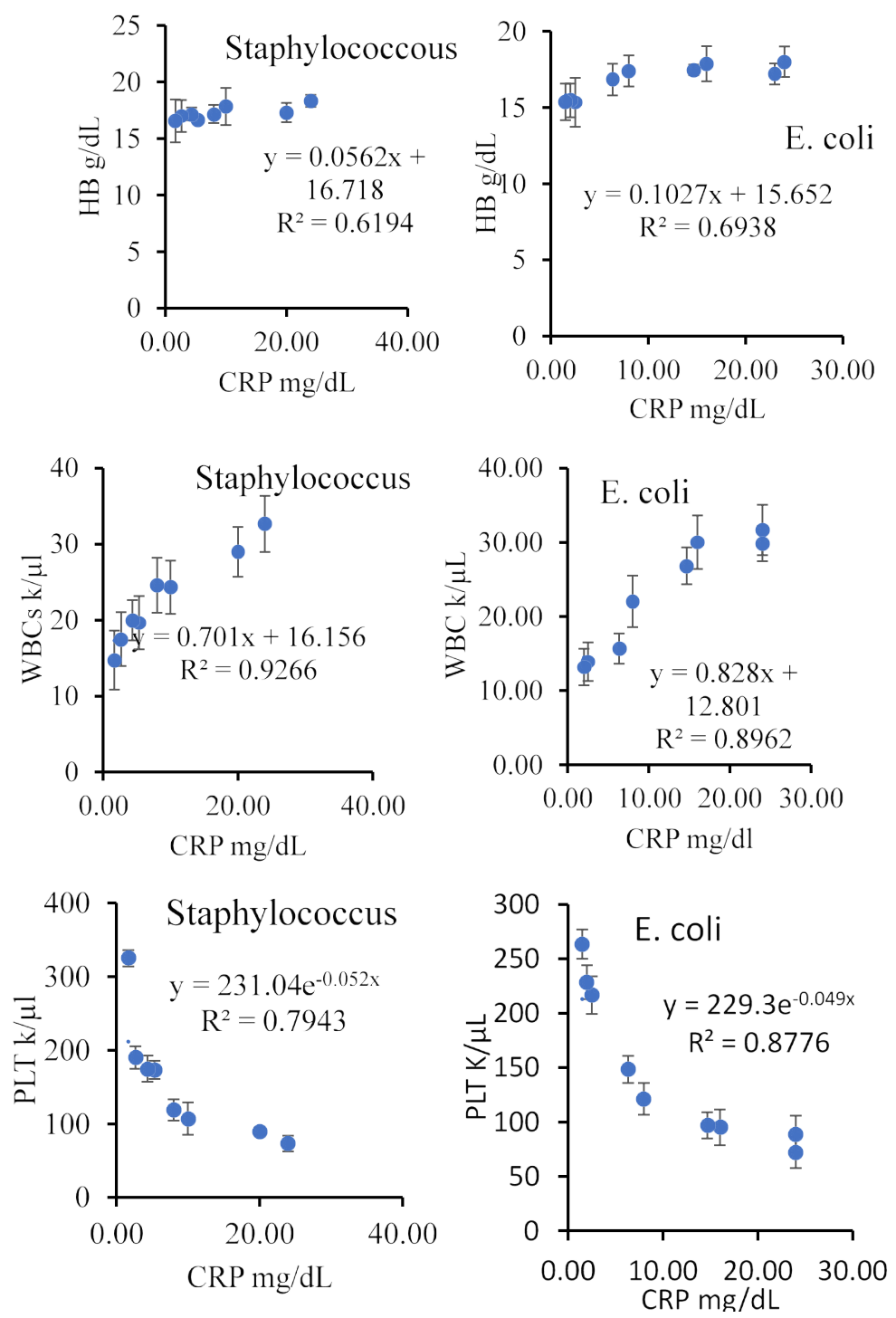

Figure 2. Correlations between CRP and HB and WBC and PLT in sepsis cases with E. coli and Staphylococcus aureus. Error bars represent the standard error

infection, the author scores seven biomarkers to assess their adequacy in being cumulative diagnostic parameters associated with sepsis in neonates. These parameters are positive blood culture microbe test, WBC and platelet counts, concentrations of CRP, and activity of each enzyme, i.e., ALT, AST, and ALP. These parameters have high value in this study.

For instance, an elevated level of the WBC count indicated an infection with microbes. This is evidence from the results of blood culture and in accordance with Díaz et al. [28], who analyzed the usefulness of WBC count along with other blood parameters for the diagnosis of invasive bacterial infections and revealed the importance of WBC along with other blood parameters to confirm or dismiss the presence of invasive bacterial infections in infants. A similar observation was found by Zarkesh et al. [29], who emphasized the diagnostic value of WBC count, along with other blood parameters, to predict serious bacterial infections in febrile infants. Furthermore, the data in Table 2 clearly show a lower value of platelets on the $1^{\text {st }}$ day of medical treatment compared with the other days. Then, the platelet level tends to increase and become closer to the normal range. Our results agree with those of Zhao et al. [30], who found platelet count (PC), plateletcrit (PCT), and platelet distribution width values were significantly lower in the invasive fungal disease versus preterm control infants. The explanation of these results is that E. coli, Staphylococcus aureus or Klebsiella sp. may interact with the platelets, resulting in the destruction of cells; consequently, a reduced level was observed in the neonatal septic cases. Our explanation agrees with that of Martini et al. [31], who studied the bacterial contamination index in platelet concentrates obtained from the blood center of the State of Rio Grande do Sul (HEMORGS) and found that two Staphylococcus sp. were associated with platelet analysis. Furthermore, Siauw et al. [32] provided evidence of the direct involvement of platelets in the pathogenesis of inflammation and sepsis. The same authors revealed that several bacteria are known to directly interact with platelets, leading to activation and aggregation, a phenomenon also observed with infection with group B Streptococcus. Thus, considering platelet level as a biomarker for neonatal sepsis is in accordance with Zhao et al. [30], who revealed that platelet parameters could be useful biomarkers for the diagnosis and prognosis of neonatal invasive fungal disease. During medical treatment, a reduction in the microbial population might have occurred, resulting in increasing platelet levels. 

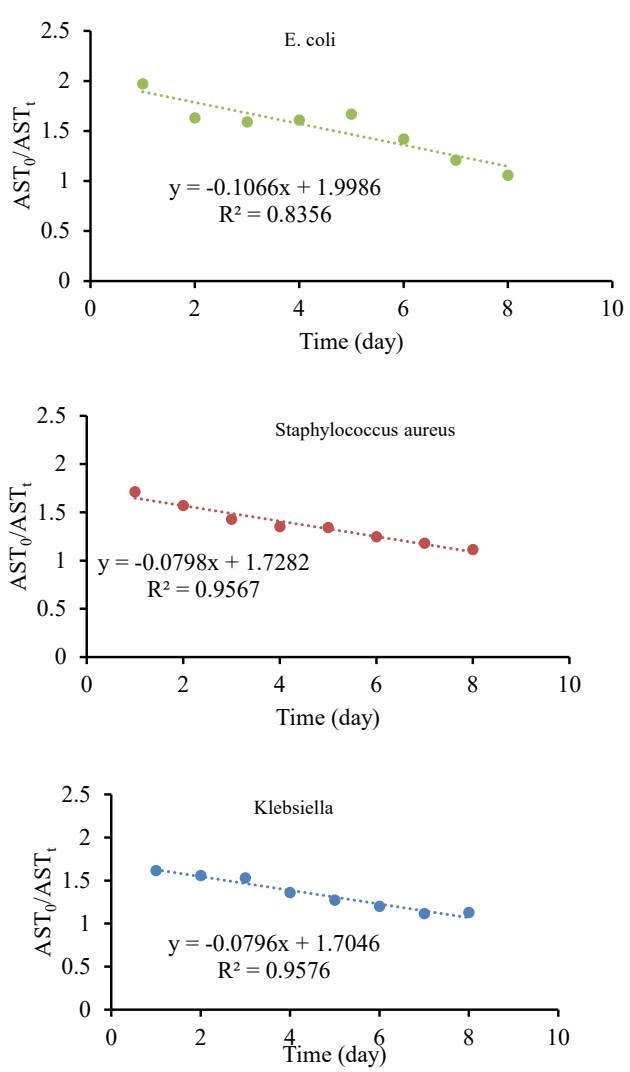

Figure 3. Relative increase in AST as affected by type of microbe

Furthermore, CRP values were higher on the $1^{\text {st }}$ day of medical treatment than the last day of medical treatment (Table 2). To date, CRP is a widely used marker of inflammation. It is synthesized by liver cells in response to pro-inflammatory cytokines as described by Marnell et al. [33]. Concentrations of CRP in blood are very low in healthy individuals (control group) but may rapidly increase after induction of an inflammatory response that is associated with microbial infections, as seen in this study. CRP has been considered a useful biomarker for many diseases such as human lung epithelial cells [34], oxidative stress [35], septic shocks [36] and neonatal sepsis [37].

The data in Table 3 clearly demonstrate elevated levels of liver biomarkers. Our results agree with Yuzurihara et al. [38], who found elevated liver enzymes (ALT and AST) in 16 patients had bilirubin measurements above $3 \mathrm{mg} / \mathrm{dl}$. Similar results were found with acute poisoning $[39,40]$. The elevation of liver enzymes indicates oxidative stress in the liver of the neonates. This can be explained by the fact that the microbes, E. coli, Staphylococcus aureus, and Klebsiella, discharged their toxins in the blood of the neonates. These toxins reached the liver and were exposed to metabolic and detoxification processes. This resulted in the elevation of liver biomarkers (ALT, AST, and ALP) as shown in Table 3. Our explanation is in accordance with Becker et al. [41], who demonstrated that $S$. aureus toxin (a-toxin) induced an activation of the acid sphingomyelinase and a concomitant release of ceramide in endothelial cells treated with the toxin. Furthermore, a similar observation was found by Bakker et al. [42], who revealed an elevation of serum alanine transaminase concentration of more than twice the upper limit in severe septic cases. In a different observation, Angus et al. [43] found hepatic failure in severe sepsis cases in seven states in the US. Furthermore, the presented results are consistent with those of Ma et al. [44], who described a novel mechanism of how $S$. aureus $\alpha$-toxin triggers activation of the acid sphingomyelinase and a release of ceramides, resulting in the release of lysosomal cathepsin B and the formation of pro-inflammatory cytokines.

As a result of the medical treatment, the growth of microbes is reduced or suppressed; thus, the amount of toxins that are produced and discharged in the blood is reduced. Liver biomarkers tended to slow down and became very close to the border line of the normal range at the end of medical treatment. The elevation of liver biomarkers was associated with high values of CRP. This observation agrees with previous reports $[14,35]$ that found oxidative stress to be associated with high values of CRP.

The data in Figure 2 clearly demonstrate a strong negative association between CRP/PLT and a strong positive association with ATL and WBCs of E. coli and Staphylococcus aureus septic cases in neonates. Similar observations were found with Klebsiella (data not shown). The relationships in both cases have exponential modes, and the $R^{2}$ values were in the range of $0.8412-0.9387$. These relationships suggest that the microbes or their toxins attack the blood system as shown by the decreased levels of platelets mentioned above (Table 1). Our suggestion agrees with Mitsiakos et al. 45, who investigated the significance of platelet (PLT) count and platelet mass (PM) in promptly predicting neonatal intracranial hemorrhage $(\mathrm{ICH})$; the results revealed that the median PLT count and PM at days 1, 2, and 3 after diagnosis of gram-negative sepsis was significantly associated with the presence of ICH. A similar observation was also obtained with Zhao et al. [30], who revealed the importance of the platelet parameter as a useful biomarker for the diagnosis of neonatal sepsis. Moreover, the data in Figure 3 clearly demonstrate the relative increase of AST as affected by the type of microbe. It is obvious that $E$. coli created the highest relative elevation of AST compared with other types of microbes. These data suggest severe damage or impairment of hepatic cells that results in AST leakage in the blood serum. This result agrees with El-Nahhal [46], who revealed an increased AST to ALT ratio because of toxic effects of zinc phosphide in humans.

Statistical analysis of the sepsis cases and control group that was generated every day (presented in Tables 2 and 3) showed significant differences during the days of medical periods; however, on the last day of medical treatment, no significant differences were detected. From the medical point of view, significant differences indicate that additional medical treatment is required for sepsis cases; in contrast, no significant differences indicate that no medical treatment is required for sepsis and that the patient can be released from the hospital.

\section{Comparison between our results and those in the literature}

A comparison between the present study and those from the literature is presented in Table 4 . It is obvious that the present study kinetically measured seven parameters of great importance for the diagnosis of septic cases among neonates. Furthermore, it dealt with 11 scientific elements to provide concrete biomarkers for the successful diagnosis and management of sepsis, whereas other studies [12,2229,31] did not measure AST, ALT and/or ALP; they measured a few biomarkers such as clinical signs, blood culture, HG, WBC, PLT and CRP. The weakness of the mentioned reports is that they did not kinetically measure the biomarkers of their concern. The presented study provided kinetic data on the importance of HG, WBC, PLT, CRP, AST, ALT, and ALP. Previous studies by Omran et al. [22], Díaz et al. [28], Zarkesh et al. [29], and Ellahony et al. [37] provided valuable data on the diagnosis of sepsis in neonates, but they dealt with few biomarkers compared with this study. It can be concluded that the 
Table 4. Comparison between our results and some from literature

\begin{tabular}{|c|c|c|c|c|c|c|c|c|}
\hline Biomarker & $\begin{array}{l}\text { Chiesa } \\
\text { et al. }[12]\end{array}$ & $\begin{array}{c}\text { Omran } \\
\text { et al. }[22]\end{array}$ & $\begin{array}{c}\text { Díaz } \\
\text { et al. }[28]\end{array}$ & $\begin{array}{l}\text { Zarkesh } \\
\text { et al. }[29]\end{array}$ & $\begin{array}{c}\text { Martini } \\
\text { et al. }[31]\end{array}$ & $\begin{array}{c}\text { Marnell } \\
\text { et al. }[33]\end{array}$ & $\begin{array}{l}\text { Ellahony } \\
\text { et al. }[37]\end{array}$ & This study \\
\hline Clinical signs & - & $\sqrt{ }$ & $\sqrt{ }$ & - & $\sqrt{ }$ & - & $\sqrt{ }$ & $\sqrt{ }$ \\
\hline Blood culture & - & - & $\sqrt{ }$ & $\sqrt{ }$ & $\sqrt{ }$ & - & & $\sqrt{ }$ \\
\hline HB & - & - & & - & - & - & $\sqrt{ }$ & $\sqrt{ }$ \\
\hline WBC & - & - & $\sqrt{ }$ & $\sqrt{ }$ & - & - & $\sqrt{ }$ & $\sqrt{ }$ \\
\hline PLT & - & $\sqrt{ }$ & & - & $\sqrt{ }$ & - & $\sqrt{ }$ & $\sqrt{ }$ \\
\hline CRP & $\sqrt{ }$ & $\sqrt{ }$ & $\sqrt{ }$ & $\sqrt{ }$ & & $\sqrt{ }$ & $\sqrt{ }$ & $\sqrt{ }$ \\
\hline AST & - & - & - & - & - & - & - & $\sqrt{ }$ \\
\hline ALT & - & - & - & - & - & - & - & $\sqrt{ }$ \\
\hline ALP & - & - & - & - & - & - & - & $\sqrt{ }$ \\
\hline $\begin{array}{l}\text { Statistical } \\
\text { correlations } \\
\text { Among } \\
\text { parameters }\end{array}$ & - & - & - & $\sqrt{ }$ & - & $\sqrt{ }$ & - & $\sqrt{ }$ \\
\hline
\end{tabular}

present study integrated the results by employing several biomarkers for the successful diagnosis and management of sepsis in neonates. This study highlights the importance of kinetic measurements and brings hope for better medical care and the reduction of morbidity and mortality in neonates.

\section{Conclusion}

The rationale of this work emerged from the fact that these seven parameters are, for the first time, being cumulatively measured in the septic cases as a successful diagnostic tool leading to successful management of the cases. Thus, the successful application of new biomarkers is based on a blood culture to identify the microbes, followed by complete blood count, CRP, ALT, AST and ALP measurements. For the successful management of the septic cases in neonates, it is necessary to kinetically measure all parameters except the blood culture. At the minimum, it is strongly recommended to kinetically measure CRP values during the medical period. In general, blood culture identification, WBC, platelets, liver biomarkers and CRP are the driving parameters in the successful diagnosis of a septic case.

\section{Acknowledgments} Germany.

Special thanks go to the AVH Foundation for research stay in

\section{Declarations}

Funding: No funds received.

Availability of data and materials: Not applicable.

Ethics approval and consent to participate: This study was approved by the research and ethical committee of toxicology at the Islamic University-Gaza and by the Helsinki ethical committee at the Ministry of Health. All ethical considerations were maintained, including subject respect, legitimacy and confidentiality. Informed consent was obtained from the parents of all the neonates throughout the study.

Consent for publication: Not applicable.

Competing interests: The authors declare that they have no competing interests.

Contributors' statement: Yasser El-Nahhal designed the experimental work, collected the results, statistically analyzed them and wrote the manuscript; Ahmed El-Shreef performed the experimental and clinical works.

\section{References}

1. Tita AT, Andrews WW (2010) Diagnosis and management of clinical chorioamnionitis. Clin Perinatol 37: 339-354. [Crossref]

2. LauraRE, Celi A, OnderdonkAB, Lieberman E (2011) Association of Epidural-Related Fever and Noninfectious Inflammation in Term Labor. Obstet Gynecol 117: 588-595. [Crossref]

3. DiGiulio DB, Romero R, Kusanovic JP, Gómez R, Kim CJ, et al. (2010) Prevalence and diversity of microbes in the amniotic fluid, the fetal inflammatory response, and pregnancy outcome in women with preterm pre-labor rupture of membranes. $\mathrm{Am} \mathrm{J}$ Reprod Immunol 64: 38-57. [Crossref]

4. Wynn JL, Levy O (2010) Role of innate host defenses in susceptibility to early-onset neonatal sepsis. Clin Perinatol 37: 307-337. [Crossref]

5. Stoll BJ, Hansen NI, Sánchez PJ, Faix RG, Poindexter BB, et al. (2011) Eunice Kennedy Shriver National Institute of Child Health and Human Development NeonatalResearch Network. Early onsetneonatal sepsis: the burden of group B Streptococcal and E. coli disease continues. Pediatrics 127: 817-826.

6. Kellogg JA, Ferrentino FL, Goodstein MH, Liss J, Shapiro SL, et al. (1997) Frequency of low level bacteremia in infants from birth to two months of age. Pediatr Infect Dis $J$ 16: 381-385. [Crossref]

7. Connell TG, Rele M, Cowley D, Buttery JP, Curtis N (2007) How reliable is a negative blood culture result? Volume of blood submitted for culture in routine practice in a children's hospital. Pediatrics 119: 891-896.

8. Nascimento-Carvalho CM, Moreno-Carvalho OA (1998) Normal cerebrospinal fluid values in full-term gestation and premature neonates. Arq Neuropsiquiatr 56: 375-380. [Crossref]

9. Smith PB, Garges HP, Cotton CM, Walsh TJ, Clark RH, et al. (2008) Meningitis in preterm neonates: importance of cerebrospinal fluid parameters. Am J Perinatol 25: 421-426. [Crossref]

10. Kestenbaum LA, Ebberson J, Zorc JJ, Hodinka RL, Shah SS (2010) Defining cerebrospinal fluid white blood cell count reference values in neonates and young infants. Pediatrics 125: 257-264. [Crossref]

11. Shah SS, Ebberson J, Kestenbaum AL, Hodinka RL, Zorc JJ (2011) Age-specific reference values for cerebrospinal fluid protein concentration in neonates and young infants. J Hosp Med 6: 22-27. [Crossref]

12. Chiesa C, Natale F, Pascone R, Osborn JF, Pacifico L, et al. (2011) C- reactive protein and procalcitonin: reference intervals for preterm and term newborns during the early neonatal period. Clin Chim Acta 412: 1053-1059. [Crossref]

13. Yao Y, Tu Y, Lu Q (2015) Values of C-reactive protein, percentage of neutrophils and mean platelet volume in early diagnosis of neonatal sepsis. Zhongguo Dang Dai Er Ke Za Zhi 17: 425-429. [Crossref]

14. Shabaan AE, Elbaz LM, El-Emshaty WM, Shouman B (2017) Role of serum 1,33-dglucan assay in early diagnosis of invasive fungal infections in a neonatal intensive care unit. J Pediatr (Rio J). [Crossref]

15. Newman TB, Puopolo KM, Wi S, Draper D, Escobar GJ (2010) Interpreting complete blood counts soon after birth in newborns at risk for sepsis. Pediatrics 126: 903-909. [Crossref] 
16. Schmutz N, Henry E, Jopling J, Christensen RD (2008) Expected ranges for blood neutrophil concentrations of neonates: the Manroe and Mouzinho charts revisited. $J$ Perinatol 28: 275-281. [Crossref]

17. Gerdes JS, Polin RA (1987) Sepsis screen in neonates with evaluation of plasma fibronectin. Pediatr Infect Dis J 6: 443-446. [Crossref]

18. Manzoni P, Mostert M, Galletto P, Gastaldo L, Gallo E, et al. (2009) Is thrombocytopenia suggestive of organism-specific response in neonatal sepsis? Pediatr Int 51: 206-210. [Crossref]

19. Guida JD, Kunig AM, Leef KH, McKenzie SE, Paul DA (2003) Platelet count and sepsis in very low birth weight neonates: is there an organism-specific response? Pediatrics 111: 1411-1415. [Crossref]

20. Vouloumanou EK, Plessa E, Karageorgopoulos DE, Mantadakis E, Falagas ME (2011) Serum procalcitonin as a diagnostic marker for neonatal sepsis: a systematic review and meta-analysis. Intensive Care Med 37: 747-762. [Crossref]

21. Tatura SNN, Wowor EC, Mandei JM, Wilar R, Warouw SM, et al. (2018) Case Report: Severe Plasmodium vivax Malaria Mimicking Sepsis in a Neonate. Am J Trop Med Hyg 98: 656-659. [Crossref]

22. Omran A, Maaroof A, Saleh HM, Abdelwahaba A (2018) Salivary C-reactive protein, mean platelet volume and neutrophil lymphocyte ratio as diagnostic markers for neonatal sepsis. J Pediatr (Rio J) 94: 82-87. [Crossref]

23. Sirdah MM, Al Laham AN, El Madhoun AR (2013) Possible health effects of liquefied petroleum gas on workers at filling and distribution stations of Gaza governorates. East Mediterr Health J 19: 289-294. [Crossref]

24. Ministry of Health (2016) Manual of medical laboratory. PNA, Palestine

25. Kid PRN, King EG (1954) Colorimetric determination of alkaline phosphatase activity. J Clin Path 6: 322

26. Reitman S, frankel S (1957) A colorimetric method for the determination of serum glutamic oxalacetic and glutamic pyruvic transaminases. Am J Clin Pathol 28: 56-63. [Crossref]

27. El-Nahhal Y, El-Dahdouh N, Hamdona N, Alshanti A(2016) Toxicological data of some antibiotics and pesticides to fish, mosquitoes, cyanobacterial mats and to plants. Data Brief 6: 871-880. [Crossref]

28. Díaz MG, García RP, Gamero BD, González-Tomé MI, Romero PC, et al. (2016) Lack of Accuracy of Biomarkers and Physical Examination to Detect Bacterial Infection in Febrile Infants. Pediatr Emerg Care 32: 664-668. [Crossref]

29. Zarkesh M, Sedaghat F, Heidarzadeh A, Tabrizi M, Bolooki-Moghadam K, et al. (2015) Diagnostic value of IL-6, CRP, WBC, and absolute neutrophil count to predict serious bacterial infection in febrile infants. Acta Med Iran 53: 408-411. [Crossref]

30. Zhao D, Qiu G, Luo Z, Zhang Y (2015) Platelet parameters and (1, 3)- $\beta$-D-glucan as a diagnostic and prognostic marker of invasive fungal disease in preterm infants. PLoS One 10: e0123907. [Crossref]

31. Martini R, Horner R, Rodrigues Mde A, Kempfer CB, Tizotti MK, et al. (2012) Bacteriological analysis of platelets and cases of septic reactions associated with transfusion of contaminated samples. Transfus Apher Sci 47: 313-318. [Crossref]
32. Siauw C, Kobsar A, Dornieden C, Beyrich C, Schinke B, et al. (2006) Group B streptococcus isolates from septic patients and healthy carriers differentially activate platelet signaling cascades. Thromb Haemost 95: 836-849. [Crossref]

33. Marnell L, Mold C, Du Clos TW (2005) C-reactive protein: ligands, receptors and role in inflammation. Clin Immunol 117: 104-111. [Crossref]

34. Agassandian M, Shurin GV, Ma Y, Shurin MR (2014) C-reactive protein and lung diseases. Int J Biochem Cell Biol 53: 77-88. [Crossref]

35. Ramage L, Proudfoot L, Guy K (2004) Expression of C-reactive protein in human lung epithelial cells and upregulation by cytokines and carbon particles. Inhal Toxicol 16 607-613. [Crossref]

36. Unnewehr H, Rittirsch D, Sarma JV, Zetoune F, Flierl MA, et al. (2013) Changes and regulation of the $\mathrm{C} 5 \mathrm{a}$ receptor on neutrophils during septic shock in humans. $J$ Immunol 190: 4215-4225. [Crossref]

37. Ellahony DM, El-Mekkawy MS, Farag MM (2017) A Study of Red Cell Distribution Width in Neonatal Sepsis. Pediatr Emerg Care. [Crossref]

38. Yuzurihara SS, Ao K, Hara T, e Tanaka F, Mori M, et al. (2013) Human parechovirus-3 infection in nine neonates and infants presenting symptoms of hemophagocytic lymphohistiocytosis. J Infect Chemother 19: 144-148. [Crossref]

39. El-Nahhal Y (2017) Risk Factors among Greenhouse Farmers in Gaza Strip. Occup Dis Environ Med 5: 1-10.

40. El-Nahhal Y (2017) Acute Poisoning among Farmers by Chlorpyrifos: Case Report from Gaza Strip. Occup Dis Environ Med 5: 47-57.

41. Becker AK, Fahsel B, Kemper H, Mayeres J, Li C, et al. (2017) Staphylococcus aureus $\alpha$-toxin disrupts endothelial tightjunctions via acid sphingomyelinase and ceramide. Infect Immun. [Crossref]

42. Bakker J, Grover R, McLuckie A, Holzapfel L, Andersson J, et al. (2004) Administration of the nitric oxide synthase inhibitor NG-methyl-L-arginine hydrochloride (546C88) byintravenous infusion for up to 72 hours can promote the resolution of shock in patients with severe sepsis: results of a randomized, doubleblind, placebo-controlled multicenter study (study no. 144-002). Crit Care Med 32: 1-12. [Crossref]

43. Angus DC, Linde-Zwirble WT, Lidicker J, Clermont G, Carcillo J, et al. (2001) Epidemiology of severe sepsis in the United States: analysis of incidence, outcome, and associated costs of care. Crit Care Med 29: 1303-1310. [Crossref]

44. Ma J, Gulbinsa E, Edwards JM, Caldwell CC, Fraunholz M, et al. (2017) Staphylococcus aureus $\alpha$-Toxin Induces Inflammatory Cytokines via Lysosomal Acid Sphingomyelinase and Ceramides. Cell Physiol Biochem 43: 2170-2184. [Crossref]

45. Mitsiakos G, Pana ZD, Chatziioannidis I, Piltsouli D, Lazaridou E, et al. (2015) Platelet Mass Predicts Intracranial Hemorrhage in Neonates with Gram-negative Sepsis. $J$ Pediatr Hematol Oncol 37: 519-523. [Crossref]

46. El-Nahhal Y (2018) Accidental Zinc Phosphide Poisoning Among population: A case report. Occup Dis Environ Med 6: 37-49.

Copyright: (C2018 El-Nahhal Y. This is an open-access article distributed under the terms of the Creative Commons Attribution License, which permits unrestricted use, distribution, and reproduction in any medium, provided the original author and source are credited. 